\title{
PENGARUH GAYA HIDUP DAN KELAS SOSIAL TERHADAP KEPUTUSAN PEMBELIAN KONSUMEN SMARTPHONE ADVAN PADA MAHASISWA PROGRAM STUDI MANAJEMEN FAKULTAS EKONOMI DAN BISNIS UNIVERSITAS MUHAMMADIYAH TANGERANG
}

\author{
Hendi Eka Sumarga, S.Pd., MM \\ Sofyanti Ayu Lestari \\ Fakultas Ekonomi Dan Bisnis \\ Universitas Muhammadiyah Tangerang
}

\begin{abstract}
ABSTRAK
Tujuan dari penelitian ini adalah untuk menganalisis pengaruh gaya hidup dan kelas sosial terhadap keputusan pembelian konsumen Smartphone Advan Pada Mahasiswa Program Studi Manajemen Fakultas Ekonomi dan Bisnis Universitas Muhammadiyah Tangerang. Penelitian ini adalah penelitian kuantitatif.

Populasi dalam penelitian ini adalah Mahasiswa Program Studi Manajemen Fakultas Ekonomi dan Bisnis Universitas Muhammadiyah Tangerang sebanyak 3122 Mahasiswa. Sampel ditentukan dengan metode incidental sampling dan memperoleh 97 responden sebagai sampel. Metode analisis yang digunakan adalah model regresi linier berganda dengan menggunakan software SPSS versi 21.

Hasil penelitian menunjukkan bahwa secara parsial variabel Gaya Hidup (X1) berpengaruh secara positif terhadap Keputusan Pembelian (Y). Hal ini ditunjukkan dengan $t_{\text {hitung }}>t_{\text {tabel }}$ yakni $9,086>1,985$, dan Kelas Sosial (X2) berpengaruh secara positif terhadap Keputusan Pembelian (Y). Hal ini ditunjukkan dengan $t_{\text {hitung }}>t_{\text {tabel }}$ yakni 7,654 $>1,985$ dan nilai signifikan regresi sebesar 0,000 lebih kecil dari 0,050. Dan secara simultan variabel Gaya Hidup (X1) dan Kelas Sosial (X2) berpengaruh secara positif terhadap Keputusan Pembelian (Y) yakni $\mathrm{F}_{\text {hitung }}>\mathrm{F}_{\text {tabel }}$ sebesar 55,016 $>3,09$. Dengan nilai persamaan regresi berganda $\mathrm{Y}=$ $14,208+0,908 \mathrm{X} 1+0,834 \mathrm{X} 2$ dengan koefisien determinasi sebesar 52,9\% yang sisanya dipengaruhi oleh faktor yang tidak diteliti.

Kata kunci : Gaya Hidup, Kelas Sosial, Keputusan Pembelian
\end{abstract}

\section{PENDAHULUAN \\ Latar Belakang}

Di era globalisasi seperti saat ini istilah teknologi tidaklah asing dan sangat erat dalam kehidupan setiap harinya. Perkembangan teknologi informasi dan telekomunikasi pada saat ini semakin mengalami kemajuan dan kompleksitas dalam kebutuhan berkomunikasi antar individu di berbagai lapisan masyarakat mulai dari kalangan atas, menengah hingga kalangan bawah. Kemudahan dan kehandalan komunikasi yang tercipta saat ini memberikan motivasi setiap masyarakat untuk dapat berinteraksi secara sistematis, cepat, mudah dan 
murah serta terhubung dimana dan kapan saja mereka inginkan.

Keputusan

pembelian

merupakan suatu konsep dalam perilaku pembelian dimana konsumen memutuskan untuk bertindak atau melakukan sesuatu dan dalam hal ini melakukan pembelian ataupun memanfaatkan produk dan jasa tertentu.

Saat proses pengambilan keputusan pembelian, konsumen memiliki beberapa pilihan pembelian dan memiliki kewajiban untuk membayar sehingga dapat menggunakan barang atau jasa yang dibayar.

Berdasarkan

data

(www.kominfo.com)

Pengguna

smartphone Indonesia tumbuh dengan ketat. Jumlah penduduk Indonesia yang mencapai 250 juta jiwa adalah pasar yang besar. Lembaga riset digital marketing Emarketer memperkirakan pada 2018 jumlah pengguna aktif smartphone di Indonesia lebih dari 100 juta orang. Dengan jumlah sebesar itu, Indonesia akan menjadi Negara dengan pengguna aktif smartphone terbesar keempat di dunia setelah Cina,India, dan Amerika.

Berdasarkan

penulis wawancara,salah satu mahasiswa Fakultas Ekonomi dan Bisnis di Universitas Muhammadiyah Tangerang. Gaya hidup mahasiswa yang muncul tercemin dari berbagai macam merek smartphone dan harga yang bervariasi. Artinya mahasiswa menunjukkan gaya hidup dan selera smartphone yang berbeda serta mengikuti trend masa kini agar tidak ketinggalan mode dari teman-teman yang lain. Namun sayangnya produk smartphone Advan yang merupakan produk smartphone lokal kurang begitu di minati oleh salah satu mahasiswa karena menurut pengalaman mahasiswa yang pernah memakai produk Smartphone Advan. Kualitas produknya kurang baik sehingga cepat terjadi kerusakan pada smartphone Advan .contohnya terjadi kerusakan pada layar dan speaker smartphone Advan yang belum lama pemakaiannya. Sehingga mahasiswa tersebut tidak tertarik lagi untuk membeli produk lokal yaitu smartphone Advan dan beralih produk ke smartphone luar negeri yang dianggap produk smartphone luar negeri lebih unggul kualitas produknya dibanding produk smartphone dalam negeri.

Hal ini berdampak pada penurunannya penjualan smartphone merek Advan. Berdasarkan data (www.seluler.id) data penjualan smartphone periode 2017-2018 sebagai berikut:

\section{Tabel 1 \\ Data penjualan smartphone 2017-2018}

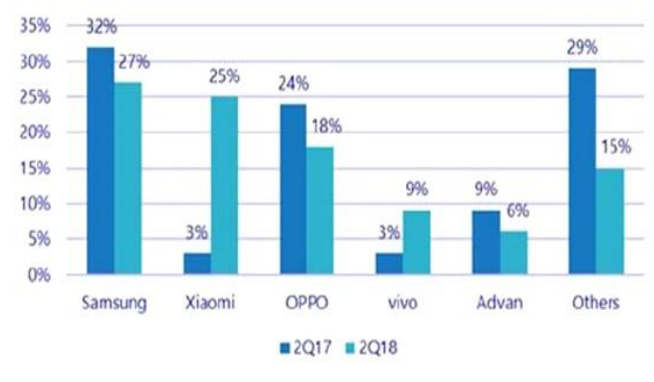

Source: IDC 2018

Ada lima smartphone yang sangat bersaing pada tahun 2018, dikutip dari (www.seluler.id diakses 09 September 2018). Lembaga riset IDC menulis laporan pasar smartphone di Indonesia pada kuartal II 2018. Samsung berada di urutan teratas dengan pangsa pasar sebesar 27 persen. Di bawah Samsung menyusul Xiomi dengan meraih peningkatan pangsa pasar sebesar 25 persen dari tahun 2017 sebesar 3 persen. Oppo meraih pangsa pasar 18 persen, menyusul Vivo dengan pangsa pasar 9 persen. Advan masih menjadi brand smartphone satu-satunya yang masuk di lima besar. Perusahaan ini menduduki posisi kelima dengan persentase angka 6 persen. Sayangnya, pencapaian ini bukan yang terbaik di periode yang sama tahun lalu, Advan 
mampu mencapai pangsa pasar 9 persen.

\section{Rumusan Masalah}

Dari batasan masalah di atas penulis dapat merumuskan pemasalahannya sebagai berikut:

1. Apakah gaya hidup berpengaruh terhadap keputusan pembelian konsumen Smartphone Advan pada Mahasiswa Program Study Manajemen Fakultas Ekonomi dan Bisnis Universitas Muhammadiyah Tangerang?

2. Apakah kelas sosial berpengaruh terhadap keputusan pembelian konsumen Smartphone Advan pada Mahasiswa Program Study Manajemen Fakultas Ekonomi dan Bisnis Universitas Muhammadiyah Tangerang?

3. Apakah gaya hidup dan kelas sosial secara bersama-sama berpengaruh terhadap keputusan pembelian konsumen Smartphone Advan pada Mahasiswa Program Study Manajemen Fakultas Ekonomi dan Bisnis Universitas Muhammadiyah Tangerang?

\section{Tujuan Penelitian}

Sesuai dengan rumusan maslah di atas maka tujuan penelitian ini adalah.

1. Untuk mengetahui pengaruh gaya hidup terhadap keputusan pembelian konsumen Smartphone Advan pada Mahasiswa Program Study Manajemen Fakultas Ekonomi dan Bisnis di Universitas Muhammadiyah Tangerang.

2. Untuk mengetahui pengaruh kelas sosial terhadap keputusan pembelian konsumen Smartphone Advan pada Mahasiswa Program Study Manajemen Fakultas Ekonomi dan Bisnis di Universitas Muhammadiyah Tangerang.
3. Untuk mengetahui pengaruh gaya hidup dan kelas sosial secara bersama-sama berpengaruh terhadap keputusan pembelian konsumen Smartphone Advan pada Mahasiswa Program Study Manajemen Fakultas Ekonomi dan Bisnis di Universitas Muhammadiyah Tangerang.

\section{TINJAUAN PUSTAKA}

\section{Gaya Hidup}

Menurut Dr. Sudaryono (2014:152), mendefinisikan gaya hidup merupakan pola hidup yang menentukan bagaimana seseorang memilih untuk menggunakan waktu, uang dan energi dan merefleksikan nilai-nilai, rasa, dan kesukaan.

Menurut Minor dan Mowen dalam Sumarwan ( 2014:45) Gaya hidup adalah mencerminkan pola konsumsi yang menggambarkan pilihan seseorang bagaimana ia menggunakan waktu dan uang.

Menurut Suwarman (2014:45)

Gaya hidup sering kali digambarkan dengan kegiatan, minat, dan opini dari seseorang. Gaya hidup seseorangbiasanya tidak permanen dan cepat berubah.Seseorang mungkin dapat cepat mengganti modal dan merek pakaiannya karena menyesuaikan dengan perubahan hidupnya.

Adapun indikator gaya hidup menurut Ujang Sumarwan (2014:47) sebagai berikut :

1. Belanja

Salah satu kegiatan "membeli" di toko atau retail yang dilakukan oleh manusia dalam memenuhi kebutuhan mereka.

2. Keluarga

Beberapa orang yang terkumpul dan tinggal di suatu tempat di bawah 
suatu atap dalam keadaan saling ketergantungan.

3. Diri sendiri

Pandangan seseorang tentang dirinya sendiri yang menyangkut apa yang ia ketahui dan rasakan tentang perilakunya.

4. Isu sosial

Sesuatu yang terdapat pada diri kita sendiri yang terkadang membuat kita berbuat sesuatu yang tidak ingin kita lakukan, kita melakukannya hanya untuk mendapatkan pengakuan, atau sebaliknya, membuat kita tidak melakukan sesuatu karena dianggap bisa menurunkan gengsi.

\section{Kelas Sosial}

Menurut Sudaryono (2014:110) Kelas sosial adalah kelas sosial yang memiliki tingkatan-tingkatan dari yang paling rendah sampai yang paling tinggi. Orang yang dari kelas tertentu menganggap orang dari kelas sosial lain memiliki status yang lebih tinggi atau lebih rendah darinya. Kelas sosial adalah sesuatu yang multidimensional, dan tidak dapat diidentifikasikan hanya dengan pendapatan.

Menurut Ujang Samarwan (2014:264) Kelas sosial adalah bentuk lain dari pengelompokan masyarakat ke dalam kelas atau kelompok yang berbeda. Kelas sosial akan mempengaruhi jenis produk, jenis jasa, dan merek yang dikonsumsi konsumen. kelas sosial juga mempengaruhi pemilihan toko, tempat pendidikan, dan tempat berlibur dari seorang konsumen.

Menurut Usman Effendi dan Alwin R.Batubara (2016:71) Kelas sosial adalah istilah yang biasanya identic dengan kelas sosial-ekonomi, didefinisikan sebagai orang yang memiliki status sosial, ekonomi, atau pendidikan yang sama.
Kelas sosial atau golongan sosial memiliki tafsiran namun lebih cenderung kepada pembagian kelas berdasarkan tingkatan ekonomi. Menurut Kotler dalam Ahrul Ainul Yakin (2016:02) indikator kelas sosial sebagai berikut :

1. Kekayaan

Untuk memahami peran uang dalam menentukan kelas sosial. Kita harus menyadari bahwa pada dasarnya kelas sosial merupakan cara hidup.

2. Pekerjaan

Suatu pekerjaan di jadikan indikator penentu kelas sosial adalah karena suatu pekerjaan memiliki tingkah kehormatan di mata masyarakat yang bisa berkaitan dengan gaya hidup seseorang. Semakin baik jenis pekerjaan yang dimiliki, maka semakin tinggi pula tingkat pendapatannya.

3. Pendidikan

Pendidikan menjadi indikator penentu kelas sosial, karena semakin tinggi pendidikan yang diambil oleh seseorang, maka semakin tinggi pula pendapatan yang akan diraihnya.

\section{Keputusan Pembelian}

Menurut Buchari Alma
(2018:96) menyatakan bahwa "Keputusan pembelian adalah suatu keputusan konsumen yang dipengaruhi oleh ekonommi keuangan, teknologi, politik budaya, produk, harga lokasi, promosi, physical evidence, people dan process.Sehingga membentuk suatu sikap pada konsumen untuk mengeolah segala informasi dan mengambil kesimpulan berupa respon yang muncul produk apa yang akan dibeli".

Menurut Assauri dalam Eva Cahya (2016:139) keputusan pembelian merupakan suatu proses pengambilan keputusan akan 
pembelian yang mencakup penentuan apa yang akan dibeli atau tidak melakukan pembelian dan keputusan itu diperoleh dari kegiatan kegiatan sebelumnya.

Menurut Kotler dan Amstrong dalam Tunjungsari (2015:181) keputusan pembelian adalah tahap dalam proses pengambilan keputusan pembeli dimana konsumen membeli merek yang paling disukai.

Menurut Kotler dan Keller dalam Katrin (2016:251) terdapat beberapa indikator dalam proses keputusan pembelian, yaitu :

1. Keunggulan produk

2. Manfaat produk

3. Pemilihan produk

4. Ketertarikan pada merek

5. Penyesuaian harga

6. Kemudahan mendapatkan produk yang diinginkan

7. Pelayanan yang diberikan

8. Keputusan jumlah pembelian

9. Kesesuaian dengan kebutuhan

10. Menentukan metode pembayaran yang akan digunakan saat transaksi.

\section{Penelitian Terlebih Dahulu}

1. Ahmad Rozain (2017) ) melakukan penelitian yang berjudul "Pengaruh celebrity endorser, gaya hidup, dan media iklan terhadap keputusan pembelian" erdasarkan analisis uji t diperoleh hasil $t_{\text {hitung }}>t_{\text {tabel }}$ dengan nilai 5,896>2,028 dan nilai signifikan $0,000<0,05$ yang berarti secara parsial gaya hidup berpengaruh signifikan terhadap keputusan pembeli.

2. Anwar Ibrahim (2018) melakukan penelitian yang berjudul "Pengaruh kelas sosial, gaya hidup, dan motivasi terhadap keputusan pembelian" dengan diperoleh nilai $t_{\text {hitung }}>t_{\text {tabel }} \quad 0,154>0,05$ untuk gaya hidup dan 0,144>0,05 untuk kelas sosial. Hal ini memberikan arti bahwa kelas sosial dan gaya hidup bersama-sama mempunyai pengaruh yang positif terhadap keputusan pembelian

3. Dewi, Noni Hariyanti (2015), melakukan penelitian yang berjudul "Pengaruh kelas sosial dan gaya hidup terhadap keputusan pembelian" Berdasarkan variabel kelas sosial Uji t nilai $t_{\text {hitung }}>t_{\text {tabel }}$ diperoleh 1,532>0,05, dan variabel gaya hidup memperoleh $0,468>0,05$. Hal ini memberikan arti bahwa kelas sosial dan gaya hidup bersama-sama mempunyai pengaruh yang positif terhadap keputusan pembelian

\section{Hipotesis}

1. Terdapat pengaruh gaya hidup terhadap keputusan pembelian konsumen Smartphone Advan Pada Mahasiswa Fakultas Ekonomi dan Bisnis Universitas Muhammadiyah Tangerang.

2. Terdapat pengaruh kelas sosial terhadap keputusan pembelian konsumen Smartphone Advan Pada Mahasiswa Fakultas Ekonomi dan Bisnis Universitas Muhammadiyah Tangerang.

3. Terdapat pengaruh gaya hidup dan kelas sosial secara bersama-sama terhadap keputusan pembelian konsumen Smartphone Advan Pada Mahasiswa Fakultas Ekonomi dan Bisnis Universitas Muhammadiyah Tangerang.

\section{METODE PENELITIAN}

\section{Pendekatan Penelitian}

Dalam hal ini penulis mengidentifikasi pengaruh antara variabel independen (X) yaitu gaya hidup dan kelas sosial dengan variabel dependen (Y) yaitu keputusan 
pembelian. Pendekatan yang digunakan dalam penelitian ini adalah penulis cenderung menggunakan teknik kuantitatif sebagai metode penelitian.

\section{Tempat dan Waktu Penelitian}

Tempat penelitian dilaksanakan di Universitas Muhammadiyah Tangerang, dengan subjek penelitian pada Mahasiswa program studi Manajemen Fakultas Ekonomi dan Bisnis.Data yang dapat diperoleh dari lokasi penelitian adalah data primer dan data sekunder.Adapun penelitian ini dilakukan selama bulan Maret sampai dengan Juli 2019.

\section{Populasi dan Sampel}

Menurut Juliansyah Noor (2015:147) menyatakan bahwa: "Dalam penelitian populasi digunakan untuk menyebutkan seluruh elemen/anggota dari suatu wilayah yang menjadi sasaran penelitian atau merupakan seluruh (universum) dari objek penelitian. Populasi diambil dari jumlah mahasiswa Program Study Manajemen Fakultas Ekonomi dan Bisnis Universitas Muhammadiyah Tangerang yaitu sebanyak 3122 Mahasiswa.

Menurut Juliansyah Noor (2015:147) menyatakan bahwa: "Sampel merupakan sejumlah anggota yang dipilih dari populasi."Maka pengambilan sampel (sampling) adalah proses pemilihan sejumlah elemen secukupnya dari populasi, sehingga penelitian terhadap sampel dan pemahaman tentang sifat atau karakteristiknya akan membuatkita dapat menggeneralisasikan sifat atau karakteristik tersebut dapat elemen populasi. Dilihat dari subtansi tujuan penarikan sampel yakni untuk memperoleh representasi populasi yang tepat, maka besarnya sampel yang akan diambil perlu mempertimbangkan karakteristik populasi serta kemampuan estimasi.

Adapun untuk mengetahui jumlah sampel, penulis menggunakan rumus solvin dengan perhitungan sebagai berikut:

$$
\frac{N}{1+\left(N \times e^{2}\right)}
$$

Sumber :Juliansyah Noor (2015:157)

Dimana:

$\mathrm{n}=$ Jumlah elemen/anggota sampel

$\mathrm{N}=$ Jumlah elemen / anggotapopulasi

$\mathrm{e}=$ Error level (tingkat kesalahan). Umumnya digunakan $1 \%$ atau 0,01 , $5 \%$ atau 0,05 , dan $10 \%$ atau 0,1 dan penulis menggunakan $5 \%$

Bila jumlah elemen populasi $(\mathrm{N})=3122$ Mahasiswa, error level yang ditetapkan oleh penulis $10 \%$, maka jumlah sampelnya:

$$
\begin{aligned}
& \mathrm{n}=\frac{3122}{1+\left(3122 \times 0,1^{2}\right)} \\
& n=\frac{3122}{1+3122(0,01)} \\
& n=\frac{3122}{1+31,22} \\
& n=\frac{3122}{32,22} \\
& n=96,896 \text { penulis membulatkan } \\
& \text { menjadi } 97 \\
& \text { Jadi jumlah sampel dari } \\
& \text { penelitian ini adalah sebanyak } 97 \\
& \text { Mahasiswa. }
\end{aligned}
$$

\section{Metode Pengambilan Sampel}

Berdasarkan metode dan teknik sampel, maka penelitian ini menggunakan metode nonprobability sampling dengan teknik pengambilan sampel insidental sampling.

\section{Metode Pengumpulan Data}

Teknik dalam pengumpulan data dapat dilakukan dalam berbagai cara. Dalam penelitian ini dilakukan dengan cara :

a. Angket (kuesioner) 
Menurut Juliansyah Noor (2015: 139) menyatakan bahwa: "Suatu teknik pengumpulan data dengan memberikan atau menyebar daftar pertanyaan kepada responden dengan harapan memberikan responden daftar petanyaan tersebut." Daftar pertanyaan dapat bersifat tebuka, yaitu jika jawaban tidak ditentukan sebelumnya oleh peneliti dan dapat bersifat tertutup, yaitu alternatif jawaban telah ditentukan sebelumnya oleh peneliti. Adapun instrumen daftar pertanyaan dapat berupa pertanyaan (berupa isian yang akan diisi oleh responden), checklist (berupa pilihan dengan cara memberi tanda pada kolom yang disediakan), dan skala (berupa pilihan dengan memberi tanda pada kolom berdasarkan tingkat tertentu).

b. Wawancara

Menurut Juliansyah Noor (2015: 138) menyatakan bahwa: "Wawancara merupakan salah satu teknik pengumpulan data yang dilakukan dengan berhadapan secara langsung dengan diwawancarai tetapi dapat juga diberikan daftar pertanyaan dahulu untuk dijawab pada kesempatan lain."

c. Observasi

Menurut Juliansyah Noor (2015: 140) menyatakan bahwa: "Teknik observasi menuntut adanya pengamatan dari peneliti baik secara langsung maupun tidak langsung terhadap objek penelitian." Alasan peneliti melakukan obeservasi yaitu untuk menyajikan gambaran realistis perilaku atau kejadian, menjawab pertanyaan, membantu mengerti perilaku mahasiswa, dan evaluasi yaitu melakukan pengukuran terhadap aspek tertentu melakukan umpan balik terhadap pengukuran tersebut.

\section{Metode Analisis Data}

1. Uji Validitas

Instrumen yang valid berarti alat ukur yang digunakan untuk mendapatkan data (mengukur) itu valid. Valid berarti instrumen tersebut dapat digunakan untuk mengukur apa yang seharusnya diukur menurut (Sugiyono, 2018:121).

a. Jika $\mathrm{r}$ hitung $>\mathrm{r}$ tabel maka instrument atau item item pertanyaan berkorelasi signifikan terhadap skor total (dinyatakan valid).

b. Jika $\mathrm{r}$ hitung $<\mathrm{r}$ tabel maka instrument atau item-item pertanyaan tidak berkorelasi signifikan terhadap skor total (dinyatakan tidak valid).

2. Uji Reliabilitas

Reliabilitas memiliki pengertian bahwa sebuah instrument dapat mengukur sesuatu yang diukur secara koesioner dari waktu ke waktu. Jadi kata kunci untuk syarat kualifikasi suatu instrument pengukuran adalah konsistensi atau tidak berubah-ubah menurut Sugiyono (2018:131).

1) Jika nilai alpha Cronbach $>0,60$ maka dinyatakan reliabel.

2) Jika nilai $\alpha$ lpha Cronbach $<0,60$ maka dinyatakan tidak reliabel.

3. Uji Normalitas

Uji ini dilakukan untuk melihat distribusi data dalam model penelitian. Perhitungan umumnya dilakukan dengan uji one sample kologorof-smirnov dengan taraf signifikan 0.05 sehingga data dapat disimpulkan terdistribusi dengan normal jika signifikansinya lebih besar dari $0.05(5 \%)$.

4. Uji Homogenitas

Uji homogenitas dikakukan untuk mengetahui apakah varian populasi 
sama atau tidak. Uji ini idgunakan sebagai prasyarat untuk analisis statistic yang menggunakan independent sample T-Test dan ANOVA. Jika hasil pengujian lebih besar dari $0.05(5 \%)$ maka varian dari dua kelompok atau lebih dikatakan sama atau homogen.

5. Uji Linearitas

Uji linieritas dilakukan untuk melihat linieritas hubungan antara variabel terikat dengan variabel bebas. Uji lineritas bertujuan untuk mengetahui apakah suatu variable variabel penelitian memiliki korelassi yang signifikan. Uji ini digunakan sebagai prasyarat dalam analisis korelasi atau regresi linear. Perhutungan dapat menggnakan SPSS menggunakan Test for linearity dengan tafraf signifikasi 0,05 . Jika dua variabel menghasilkan signifikasi dibawah 0,05 maka dikatakan kedua variabel tersebut mempunyai hubungan yang linear.

6. Uji Multikolinearitas

Multikolinearitas merupakan salah satu asumsi dalam penggunaan alisis regresi. Pada analisis ini menggunakan nilai tolerance lebih besar dari 10 atau nilai VIF kurang dari 10 artinya tidak terjadi multikolinearitas.

7. Uji Heteroskedastisitas

uji untuk mengetahui variabel pengganggu dalam persamaan regresi mempunyai varians yang sama atau tidak. Jika mempunyai varians yang sama, berarti tidak terdapat heteroskedastisitas, sedangkan jika mempunyai varians yang tidak sama maka terdapat heteroskedastisitas.

8. Uji Autokorelasi

untuk mengetahui ada atau tidaknya korelasi antara variabel yang diteliti dengan perubahan waktu yang diamati.
9. Analisis Regresi Sederhana analisis ini dapat digunakan untuk melakukan prediksi seberapa tinggi nilai variabel dependen bila nilai variabel idependen dirubah-rubah.

10. Analisis Regresi Berganda

Analisis ini digunakan untuk mengetahui seberapa besar determinasi variabel bebas yaitu gaya hidup $\left(\mathrm{X}_{1}\right)$ dan kelas sosial $\left(\mathrm{X}_{2}\right)$ terhadap variabel terikatnya yaitu keputusan pembelian (Y).

11. Uji Korelasi Sederhana analisis ini akan digunakan dalam menguji besarnya pengaruh dan kontribusi variabel $\mathrm{X}$ dan variabel Y. Analisis korelasi sederhana digunakan untuk mengetahui keeratan gabungan antara dua variabel. Untuk mengetahui arah yang terjadi antara dua variabel.

12. Uji Korelasi berganda

Koefisien korelasi berganda adalah alat analisis yang menunjukkan keeratan hubungan antara variabel independen (gaya hidup dan kelas sosial) terhadap variabel dependen (keputusan pembelian).

13. Koefisien Determinasi

kuadrat dari koefisien korelasi PPM yang dikalikan dengan $100 \%$. Dilakukan untuk mengetahui seberapa besar variabel $\mathrm{X}$ mempunyai sumbangan atau ikut menentukan variabel $\mathrm{Y}$. Uji $\mathrm{t}$ (Parsial)

Uji yang digunakan untuk menyatakan signifikan pengaruh variabel bebas secara parsial terhadap variabel terkait.

14. Uji f (Simultan)

Digunakan untuk mengetahui pengaruh antara dua variabel bebas terhadap variabel terkait secara simultan, sehingga bisa diketahui apakah dengan yang sudah ada dapat diterima atau ditolak. 


\section{HASIL PENELITIAN DAN PEMBAHASAN}

1. Uji Validitas

Tabel 2

Uji Validitas

\begin{tabular}{|c|c|c|c|}
\hline Variabel & $\mathrm{r}$ Hitung & $\begin{array}{c}\mathrm{r} \\
\text { Tabel }\end{array}$ & $\begin{array}{c}\text { Ketera } \\
\text { ngan }\end{array}$ \\
\hline \multirow{2}{*}{$\begin{array}{c}\text { Gaya } \\
\text { hidup } \\
(\mathrm{X} 1)\end{array}$} & 0,664 & 0,361 & Valid \\
\cline { 2 - 4 } & 0,790 & 0,361 & Valid \\
\cline { 2 - 4 } & 0,840 & 0,361 & Valid \\
\cline { 2 - 4 } $\begin{array}{c}\text { Kelas } \\
\text { Sosial } \\
(X 2)\end{array}$ & 0,828 & 0,361 & Valid \\
\cline { 2 - 4 } & 0,833 & 0,361 & Valid \\
\cline { 2 - 4 } $\begin{array}{c}\text { Keputusan } \\
\text { Pembelian }\end{array}$ & 0,867 & 0,361 & Valid \\
\cline { 2 - 4 } & 0,449 & 0,361 & Valid \\
\hline
\end{tabular}

One-Sample Kolmogorov-Smirnov Test

\begin{tabular}{|ll|r|}
\hline & & $\begin{array}{c}\text { Unstandardized } \\
\text { Residual }\end{array}$ \\
\hline $\mathrm{N}$ & Mean & 97 \\
Normal & Std. &, 0000000 \\
Parameters ${ }^{\mathrm{a}, \mathrm{b}}$ & Deviation & 3,01984812 \\
& Absolute &, 084 \\
Most Extreme & Positive &, 084 \\
Differences & Negative &,- 062 \\
Kolmogorov-Smirnov Z &, 830 \\
Asymp. Sig. (2-tailed) &, 495 \\
\hline
\end{tabular}

a. Test distribution is Normal.

b. Calculated from data.

\begin{tabular}{|c|c|l|c|}
\hline Keputusan & 0,624 & 0,361 & Valid \\
\cline { 2 - 4 } Pembelian & 0,413 & 0,361 & Valid \\
\cline { 2 - 4 } & 0,516 & 0,361 & Valid \\
\cline { 2 - 4 } & 0,531 & 0,361 & Valid \\
\cline { 2 - 4 } & 0,562 & 0,361 & Valid \\
\cline { 2 - 4 } & 0,475 & 0,361 & Valid \\
\cline { 2 - 4 } & 0,77 & 0,361 & Valid \\
\hline
\end{tabular}

\begin{tabular}{|c|c|c|c|}
\hline Variabel & $\begin{array}{c}\text { Cronbach } \\
\text { Alpha }\end{array}$ & $\alpha$ & Keterangan \\
\hline X1 & 0,789 & 0,60 & Reliabel \\
\hline $\mathrm{X} 2$ & 0,689 & 0,60 & Reliabel \\
\hline Y & 0,740 & 0,60 & Reliabel \\
\hline
\end{tabular}

Slimibaliạlata yang diolah SPSS 21

Dari tabel diatas dapat dilihat bahwa masing-masing item pernyataan variabel memiliki $\mathrm{r}$ hitung $>\mathrm{r}$ tabel $(0,361)$ dan bernilai positif. Dengan demikian maka semua butir pernyataan tersebut dinyatakan valid.

2. Uji Reliabilitas

Tabel 3

\section{Uji Reliabilitas}

Sumber : data yang diolah SPSS 21

Tabel diatas menunjukan bahwa koefisien Cronbach's Alpha untuk setiap

Test of Homogeneity of Variances

Keputusan Pembelian

\begin{tabular}{|r|r|r|r|}
\hline Levene Statistic & df1 & df2 & Sig. \\
\hline 1,012 & 7 & 86 &, 428 \\
\hline
\end{tabular}

variabel > 0,060 yang berarti dinyatakan handal atau reliabel.

\section{Uji Normalitas}

\section{Tabel 4}

Hasil Uji Normalitas Kolmogorov Smirnov Sumber : data yang diolah SPSS 21

Dari tabel diatas, nilai Asymp. Sig. nya sebesar 0,495 menunjukan bahwa nilai yang diperoleh lebih besar dari 0,05. Maka dengan demikian, data pada penelitian ini bedistribusi normal.

\section{Uji Homogenitas}

\section{Tabel 5}

Gaya Hidup (X1) Terhadap

Keputusan Pembelian (Y)

Sumber : data yang diolah SPSS 21

\section{Tabel 6}

\section{Kelas Sosial (X2) Terhadap} Keputusan Pembelian (Y)

Test of Homogeneity of Variances

Keputusan Pembelian

\begin{tabular}{|r|r|r|l|}
\hline Levene Statistic & df1 & df2 & Sig. \\
\hline, 937 & 7 & 88 &, 482 \\
\hline
\end{tabular}

Sumber : data yang diolah SPSS 21

Hasil uji homogenitas antara 
keputusan pembelian dengan gaya hidup sebesar 0,428 dan keputusan pembelian dengan kelas sosial sebesar 0,482 menunjukan bahwa nilai yang diperoleh > 0,05 maka data varian tersebut dikatakan sama atau homogen.

5. Uji Linearitas

Tabel 7

Gaya Hidup (X1) Terhadap

Keputusan Pembelian (Y)

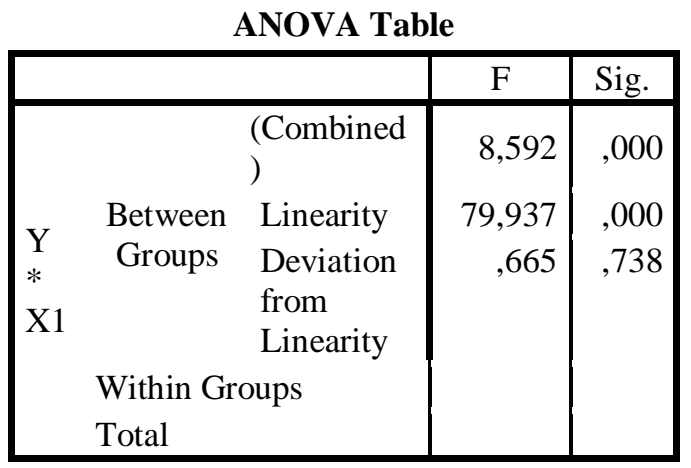

Sumber : data yang diolah SPSS 21

Berdasarkan hasil uji linearitas diketahui Sig. deviation from linearity sebesar 0,738>0,05 maka dapat disimpulkan bahwa terdapat hubungan yang linear antara gaya hidup dengan keputusan pembelian.

Tabel 8

Kelas Sosial (X2) Terhadap Keputusan Pembelian (Y)

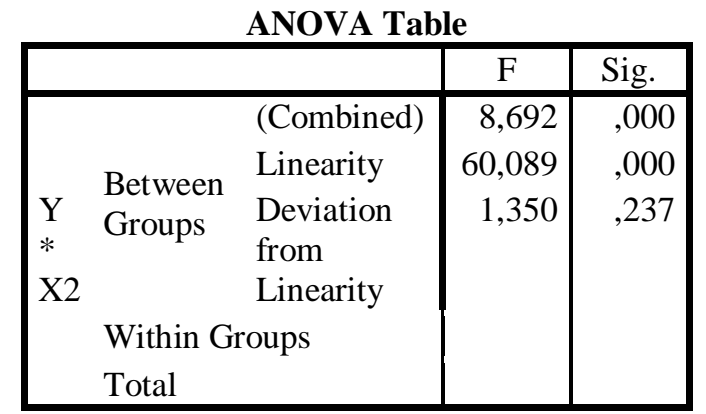

Sumber : data yang diolah SPSS 21

Berdasarkan hasil uji linearitas diketahui Sig. deviation from linearity sebesar $0,237>0,05$ maka dapat disimpulkan bahwa terdapat hubungan yang linear antara kelas sosial dengan keputusan pembelian.

\section{Uji Multikolinearitas}

Tabel 9

Hasil Uji Multikolinearitas

Coefficients $^{\mathrm{a}}$

\begin{tabular}{|ll|r|r|}
\hline \multirow{2}{*}{ Model } & \multicolumn{2}{|c|}{ Collinearity Statistics } \\
\cline { 2 - 4 } & Tolerance & \multicolumn{1}{c|}{ VIF } \\
\hline \multirow{2}{*}{1} & Gaya Hidup &, 664 & 1,507 \\
& Kelas Sosial &, 664 & 1,507 \\
\hline
\end{tabular}

a. Dependent Variable: Keputusan Pembelian Sumber : data yang diolah SPSS 21

Dari hasil uji diatas nilai Tolerance yang diperoleh sebesar $0,664>0,10$ dan nilai VIF sebesar 1,507 < 10 maka dapat disimpulkan bahwa data tersebut tidak terjadi multikolinearitas.

\section{Uji Heteroskedastisitas}

Tabel 10

Hasil Uji Heteroskedastisitas Coefficients $^{\text {a }}$

\begin{tabular}{|c|c|c|}
\hline Model & $\mathrm{T}$ & Sig. \\
\hline (Constant) & 2,074 & 0,041 \\
\hline Gaya Hidup & $-0,57$ & 0,570 \\
\hline Kelas Sosial & 0,01 & 0,992 \\
\hline
\end{tabular}

a.Dependent Variable: Keputusan Pembelian Sumber : data yang diolah SPSS 21

Dari hasil uji diatas, hasil nilai signifkan variabel gaya hidup sebesar $0,570>0,05$ maka dapat disimpulkan tidak terjadi heteroskedasitas. Dan hasil nilai signifikan variabel kelas sosial sebesar 0,992 > 0,05 maka dapat disimpulkan tidak terjadi heteroskedasitas.

\section{Uji Autokorelasi}

\section{Tabel 11}

\section{Uji Autokorelasi}


Sumber : data yang diolah SPSS 21

Hasil uji Durbin-Watson menunujukan nilai D-W sebesar 1,906. Nilai tabel DW untuk jumlah sampel 97 (n) dengan jumlah variabel independen $2(\mathrm{~K}=2)$ dan signifikansi $5 \%$ akan diperoleh nilai $\mathrm{dU}=1,71157$. Nilai D-W $(1,906>d U(1,71157)$ dan nilai D- W $(1,906)<4$-dU $(2,28843)$ dapat disimpulkan bahwa tidak terdapat autokerelasi.

9. Analisis Regresi Sederhana

Tabel 12

Gaya Hidup (X1) Terhadap Keputusan Pembelian (Y)

Coefficientsa

\begin{tabular}{|c|c|c|c|c|}
\hline \multirow[t]{2}{*}{ Model } & \multicolumn{2}{|c|}{$\begin{array}{c}\text { Unstandardized } \\
\text { Coefficients }\end{array}$} & \multirow[t]{2}{*}{$\mathrm{T}$} & \multirow[t]{2}{*}{ Sig. } \\
\hline & $\mathrm{B}$ & $\begin{array}{c}\text { Std. } \\
\text { Error }\end{array}$ & & \\
\hline (Constant) & 18,763 & 2,088 & 8,986 & ,000 \\
\hline $\begin{array}{ll}1 & \text { Gaya } \\
& \text { Hidup }\end{array}$ & 1,270 &, 140 & 9,086 & ,000 \\
\hline
\end{tabular}

a. Dependent Variable: Keputusan Pembelian Sumber : data yang diolah SPSS 21

Berdasarkan tabel diatas diperoleh persamaan regresi linear sederhana $\mathrm{Y}=18,763+1,270 \mathrm{X}$

Tabel 13

Kelas Sosial (X2) Terhadap Keputusan Pembelian (Y)

\begin{tabular}{|c|c|c|c|c|}
\hline \multicolumn{5}{|c|}{ Coefficients $^{\mathrm{a}}$} \\
\hline \multirow[t]{2}{*}{ Model } & \multicolumn{2}{|c|}{$\begin{array}{l}\text { Unstandardized } \\
\text { Coefficients }\end{array}$} & \multirow[t]{2}{*}{$\mathrm{T}$} & \multirow[t]{2}{*}{ Sig. } \\
\hline & B & $\begin{array}{l}\text { Std. } \\
\text { Error }\end{array}$ & & \\
\hline (Constant) & 19,248 & 2,411 & 7,984 &, 000 \\
\hline $\begin{array}{ll}1 & \text { Kelas } \\
& \text { Sosial }\end{array}$ & 1,539 & ,201 & 7,654 &, 000 \\
\hline
\end{tabular}

a. Dependent Variable: Keputusan Pembelian Sumber : data yang diolah SPSS 21

Berdasarkan tabel diatas diperoleh persamaan regresi linear sederhana $\mathrm{Y}=19,248+1,539 \mathrm{X}$
Model Summary ${ }^{b}$

\begin{tabular}{|l|c|r|r|}
\hline Model & $\mathrm{R}$ & R Square & Durbin-Watson \\
\hline 1 &, $736^{\mathrm{a}}$ &, 541 & 1,906 \\
\hline
\end{tabular}

a. Predictors: (Constant), Kelas Sosial, Gaya Hidup

b. Dependent Variable: Keputusan Pembelian

10. Analisis Regresi Berganda

Tabel 14

Hasil Uji Analisis Regresi Berganda

Coefficientsa

\begin{tabular}{|c|c|c|c|c|}
\hline \multirow[t]{2}{*}{ Model } & \multicolumn{2}{|c|}{$\begin{array}{l}\text { Unstandardize } \\
\text { d Coefficients }\end{array}$} & \multirow[t]{2}{*}{$\mathrm{t}$} & \multirow[t]{2}{*}{ Sig. } \\
\hline & $\mathrm{B}$ & $\begin{array}{l}\text { Std. } \\
\text { Error }\end{array}$ & & \\
\hline (Constant) & 14,208 & 2,272 & 6,253 &, 000 \\
\hline 1 Gaya Hidup & ,908 &, 160 & 5,675 &, 000 \\
\hline Kelas Sosial & ,834 & ,214 & 3,894 & 000 \\
\hline
\end{tabular}

a. Dependent Variable: Keputusan Pembelian Sumber : data yang diolah SPSS 21

Berdasarkan tabel diatas diperoleh persamaan regresi linear berganda

$Y=14,208+0,908 X_{1}+0,834 X_{2}+e$

11. Uji Korelasi Sederhana

Tabel 15

\section{Gaya Hidup (X1) Terhadap Keputusan Pembelian}

\begin{tabular}{|ll|r|r|}
\hline \multicolumn{4}{c|}{ Correlations } \\
\hline & $\begin{array}{c}\text { Gaya } \\
\text { Hidup }\end{array}$ & $\begin{array}{r}\text { Keputusan } \\
\text { Pembelian }\end{array}$ \\
\hline \multirow{3}{*}{ Gaya } & Pearson & 1 &, $682^{* *}$ \\
Hidup & Correlation & & \\
& Sig. (2-tailed) & &, 000 \\
& N & 97 & 97 \\
& Pearson &, $682^{* *}$ & 1 \\
Keputusan & Correlation & & \\
Pembelian & Sig. (2-tailed) &, 000 & \\
& N & 97 & 97 \\
\hline
\end{tabular}

**. Correlation is significant at the 0.01 level (2tailed).

Sumber : data yang diolah SPSS 21

Berdasarkan tabel diatas, diperoleh nilai Pearson Correlation sebesar 0,682 karena hasil tersebut 
berada diantara 0,60 - 0,799 maka dapat disimpulkan bahwa terdapat hubungan yang kuat antara variabel gaya hidup terhadap keputusan pembelian.

Tabel 16

Kelas Sosial (X2) Terhadap

Keputusan Pembelian (Y)

Correlations

\begin{tabular}{|ll|r|r|}
\hline & & $\begin{array}{r}\text { Kelas } \\
\text { Sosial }\end{array}$ & $\begin{array}{r}\text { Keputusan } \\
\text { Pembelian }\end{array}$ \\
\hline & Pearson & 1 &, $618^{* *}$ \\
Kelas & Correlation \\
Sosial & Sig. (2- & & \\
& tailed) & &, 000 \\
& $\mathrm{~N}$ & 97 & 97 \\
& Pearson &, $618^{* *}$ & 1 \\
Keputusan & $\begin{array}{l}\text { Correlation } \\
\text { Pembelian }\end{array}$ & Sig. (2- \\
& tailed) &, 000 & \\
& $\mathrm{~N}$ & 97 & 97 \\
\hline
\end{tabular}

**. Correlation is significant at the 0.01 level (2-tailed).

Sumber : data yang diolah SPSS 21

Berdasarkan tabel diatas diperoleh nilai Pearson Correlation sebesar 0,618 karena hasil tersebut berada diantara $0,60-0,799$ maka dapat disimpulkan bahwa terdapat hubungan yang kuat antara variabel kelas sosial terhadap keputusan pembelian.

\section{Uji Korelasi Berganda}

\section{Tabel 17}

Hasil Uji Korelasi Berganda Model Summary

\begin{tabular}{|l|c|r|r|c|}
\hline Model & $\mathrm{R}$ & $\begin{array}{c}\mathrm{R} \\
\text { Square }\end{array}$ & $\begin{array}{c}\text { Adjusted } \\
\text { R Square }\end{array}$ & $\begin{array}{c}\text { Std. } \\
\text { Error of } \\
\text { the } \\
\text { Estimate }\end{array}$ \\
\hline 1 &, $734^{\mathrm{a}}$ &, 539 &, 529 & 3,052 \\
\hline
\end{tabular}

a. Predictors: (Constant), Kelas Sosial, Gaya Hidup b. Dependent Variable: Keputusan Pembelian Sumber : data yang diolah SPSS 21

Berdasarkan tabel diatas, diperoleh nilai koefisien korelasi (R) sebesar 0,734 karena hasil tersebut berada diantara $0,60-0,799$ maka dapat disimpulkan bahwa terdapat hubungan yang kuat antara variabel gaya hidup dan kelas sosial terhadap keputusan pembelian.

\section{Koefisien Determinasi}

\section{Tabel 18}

\section{Hasil Uji Koefisien Determinasi}

\begin{tabular}{|l|c|r|r|c|}
\multicolumn{5}{|c|}{ Model Summary } \\
\hline Model & $\mathrm{R}$ & $\begin{array}{c}\mathrm{R} \\
\text { Square }\end{array}$ & $\begin{array}{c}\text { Adjusted } \\
\text { R Square }\end{array}$ & $\begin{array}{c}\text { Std. } \\
\text { Error of } \\
\text { the } \\
\text { Estimate }\end{array}$ \\
\hline 1 &, $734^{\mathrm{a}}$ &, 539 &, 529 & 3,052 \\
\hline
\end{tabular}

a. Predictors: (Constant), Kelas Sosial, Gaya Hidup b. Dependent Variable: Keputusan Pembelian Sumber : data yang diolah SPSS 21

Dengan melihat Adjusted R. Square dapat diketahui nilai koefisien determinasinya yaitu sebesar 0, 529 atau 52,9\%. Hal ini menunjukan bahwa variabel gaya hidup (X1) dan kelas sosial (X2) secara bersama-sama berkontribusi terhadap keputusan pembelian (Y) sebesar $52,9 \%$ dan sisanya $47,1 \%$ dipengaruhi oleh variabel lain yang tidak diteliti dalam penelitian ini.

14. Uji t (Parsial)

Tabel 19

Uji t Gaya Hidup (X1) Terhadap

Keputusan Pembelian (Y) Coefficients $^{\text {a }}$

\begin{tabular}{|c|c|c|c|c|}
\hline \multirow[t]{2}{*}{ Model } & \multicolumn{2}{|c|}{$\begin{array}{c}\text { Unstandardized } \\
\text { Coefficients }\end{array}$} & \multirow[t]{2}{*}{$\mathrm{T}$} & \multirow[t]{2}{*}{ Sig. } \\
\hline & B & $\begin{array}{l}\text { Std. } \\
\text { Error }\end{array}$ & & \\
\hline (Constant) & 18,763 & 2,088 & 8,986 & ,000 \\
\hline $\begin{array}{l}1 \text { Gaya } \\
\text { Hidup }\end{array}$ & 1,270 &, 140 & 9,086 &, 000 \\
\hline
\end{tabular}

a. Dependent Variable: Keputusan Pembelian Sumber : data yang diolah SPSS 21 
Dari tabel diatas diketahui bahwa t hitung sebesar 9,086 dengan taraf signifikansi $5 \%$. Uji 2 sisi dan $\mathrm{df}=\mathrm{n}-$ $2=97-2=95$, sehingga didapat $t$ tabel sebesar 1,985 dengan demikian dapat disimpulkan bahwa t hitung 9,086 > t tabel 1,985 dan nilai sig $0,000<0,05$ artinya $\mathrm{H} 0$ ditolak dan $\mathrm{Ha}$ diterima artinya terdapat pengaruh yang positif dan signifikan gaya hidup terhadap

keputusan pembelian.

\section{Tabel 20}

Uji t Gaya Hidup (X1) Terhadap Keputusan Pembelian (Y)

Coefficients $^{\mathrm{a}}$

\begin{tabular}{|c|c|c|c|c|}
\hline \multirow[t]{2}{*}{ Model } & \multicolumn{2}{|c|}{$\begin{array}{c}\text { Unstandardized } \\
\text { Coefficients }\end{array}$} & \multirow[t]{2}{*}{$\mathrm{T}$} & \multirow[t]{2}{*}{ Sig. } \\
\hline & B & $\begin{array}{l}\text { Std. } \\
\text { Error }\end{array}$ & & \\
\hline (Constant) & 19,248 & 2,411 & 7,984 &, 000 \\
\hline $\begin{array}{ll}1 & \text { Kelas } \\
& \text { Sosial }\end{array}$ & 1,539 & 201 & 7,654 & ,000 \\
\hline
\end{tabular}

a. Dependent Variable: Keputusan Pembelian Sumber : data yang diolah SPSS 21

Dari tabel diatas diketahui bahwa t hitung sebesar 7,654 dengan taraf signifikansi $5 \%$. Uji 2 sisi dan $\mathrm{df}=\mathrm{n}-$ $2=97-2=95$, sehingga didapat $\mathrm{t}$ tabel sebesar 1,985 dengan demikian dapat disimpulkan bahwa $\mathrm{t}$ hitung 7,654>t tabel 1,985 dan nilai sig 0,000 $<0,05$ artinya $\mathrm{H} 0$ ditolak dan $\mathrm{Ha}$ diterima artinya terdapat pengaruh yang positif dan signifikan

\section{Uji F (Simultan)}

Tabel 21

Hasil Uji F

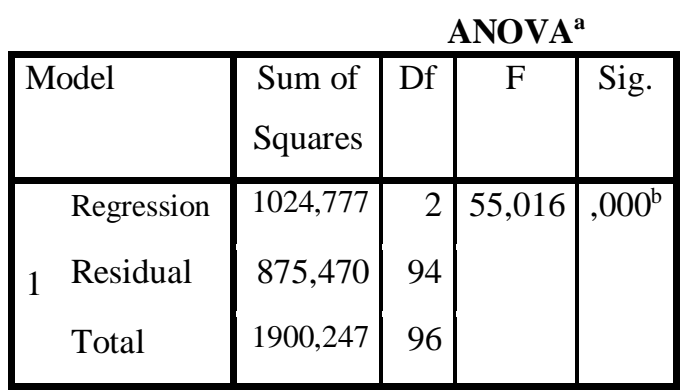

a. Dependent Variable: Keputusan Pembelian b.Predictors: (Constant), Kelas Sosial, Gaya Hidup

Sumber : data yang diolah SPSS 21

Dari tabel diatas diketahui $\mathrm{F}$ hitung sebesar 55,016 dengan taraf signifikansi 5\%, df $1=\mathrm{k}-1$ (3-1=2) dan df $2=n-k(97-3=94)$ diperoleh $F$ tabel sebesar 3,09. Dengan demikian berdasarkan hasil tabel tersebut dapat disimpulkan bahwa f hitung 55,016 > f tabel 3,09 dan nilai sig. 0,000 $<0,05$ artinya H0 ditolak dan $\mathrm{Ha}$ diterima artinya terdapat pengaruh yang positif dan signifikan gaya hidup dan kelas sosial secara bersama-sama terhadap keputusan pembelian.

\section{KESIMPULAN}

\section{Kesimpulan}

Berdasarkan hasil penelitian dan pembahasan, penulis dapat menarik kesimpulan dari penelitian ini sebagai berikut :

1. Gaya Hidup (X1) memiliki pengaruh yang positif dan signifikan terhadap keputusan pembelian (Y) smartphone Advan pada Mahasiswa Program Study Manajemen Fakultas Ekonomi dan Bisnis Universitas Muhammadiyah Tangerang. Berdasarkan hasil uji t, Gaya Hidup (X1) terhadap keputusan pembelian (Y) dengan nilai $\mathrm{t}$ hitung > t tabel $(9,086>$ 1,985) dan nilai sig $0,000<0,05$. Hal ini menunjukan $\mathrm{H} 0$ ditolak dan Ha diterima. Dengan diterimanya Ha membuktikan bahwa gaya hidup (X1) berpengaruh terhadap keputusan pembelian (Y) smartphone Advan pada Mahasiswa Program Studi Manajemen Fakultas Ekonomi dan Bisnis Universitas Muhammadiyah Tangerang. 
2. Kelas Sosial (X2) memiliki pengaruh yang positif dan signifikan terhadap keputusan pembelian (Y) smartphone Advan pada Mahasiswa Program Studi Manajemen Fakultas Ekonomi dan Bisnis Universitas Muhammadiyah Tangerang. Berdasarkan hasil uji t, kelas sosial (X2) terhadap keputusan pembelian (Y) dengan nilai $\mathrm{t}$ hitung $>\mathrm{t}$ tabel $(7,654>$ 1,985) dan nilai sig $0,000<0,05$. $\mathrm{Hal}$ ini menunjukan $\mathrm{HO}$ ditolak dan Ha diterima. Dengan diterimanya Ha membuktikan bahwa kelas sosial (X2) berpengaruh terhadap keputusan pembelian (Y) smartphone Advan pada Mahasiswa Program Studi Manajemen Fakultas Ekonomi dan Bisnis Universitas Muhammadiyah Tangerang.

3. Gaya hidup (X1) dan kelas sosial (X2) secara bersama-sama (simultan) memiliki pengaruh yang positif dan signifikan terhadap keputusan pembelian (Y) smartphone Advan pada Mahasiswa Program Studi Manajemen Fakultas Ekonomi dan Bisnis Universitas Muhammadiyah Tangerang. Berdasarkan hasil uji f, nilai f hitung > f tabel $(55,016>$ $3,09)$ dan nilai sig $0,000<0,05$. Hal ini menunjukan H0 ditolak dan Ha diterima. Dengan diterimanya Ha membuktikan bahwa gaya hidup (X1) dan kelas sosial (X2) secara bersama-sama (simultan) berpengaruh terhadap keputusan pembelian (Y) smartphone Advan pada Mahasiswa Program Studi Manajemen Fakultas Ekonomi dan Bisnis Universitas Muhammadiyah Tangerang.

\section{DAFTAR PUSTAKA}

Sudaryono. 2014. Perilaku Konsumen. Jakarta Pusat: LentaraI lmu Cendekia.

Sumarwan, Ujang. 2014. Perilaku konsumen. Bogor: Ghalia Indonesia

Usman Efendi dan Alwi 2016, Psikologi konsumen.. Jakarta: RajaGrafindo Persada.

Eva Cahya, Harti. 2016. Pengaruh Kualitas Produk Dan Harga Terhadap Keputusan Pembelian. Universitas Negeri Surabaya

Dr.Sugiyono, 2018. MetodePenelitian (Kuantitatif, Kualitatifdan $R \& D$ ). Bandung: Alfabeta

Suryabrata, Sumardi. 2014. MetodePenelitian. Jakarta: PT Raja Grafindo Persada

Noor, Juliansyah. 2015. Metodologi Penelitian. Jakarta: Kencana Prenada Media Group

Dr.Riduwan. 2018. Metode \& Teknik Menyusun Proposal Penelitian. Bandung: Alfabeta

Eksandy, A. (2018). Metode Penelitian Akuntansi dan Manajemen. Tangerang: Fakultas Ekonomi dan Bisnis. Universitas Muhammadiyah Tangerang.

Sugiyono dan Agus Susanto. 2015. Cara Mudah Belajar SPSS \& Lisrel. Bandung: Alfabeta

Alma, Buchari. 2018. Manajemen Pemasaran \& Pemasaran Jasa. Bandung: Alfabeta

Rahmayani, indah .2015. Indonesia raksasa teknologi digital Asia httpsw.kominfo.go.id/content/detai 1/6095/indonesia-raksasa-teknologi -digital-asia/0/sorotan_media. (02 Oktober 2015)

Katrin, Intan Lina dan Diyah Setyorini. 2016. Pengaruh promosi terhadap keputusan pembelian. Universitas Pendidikan Indonesia. 